Ks. Michał KIELING*

\title{
ZASADY OGÓLNE DOTYCZACCE PRAKTYK POKUTNYCH NA PODSTAWIE LIBRI POENITENTIALES
}

Pisząc na temat pokuty chrześcijańskiej zwraca się uwagę na jej podwójny aspekt: aretologiczny i sakramentalny. Pierwszy wskazuje na stałe wewnętrzne nastawienie, oznaczające moralną i religijną postawę wobec grzechu. Określa się ją jako nadprzyrodzoną sprawność moralna, która skłania człowieka do odczuwania bólu z powodu popełnionego zła. Realizacja cnoty pokuty dokonuje się przez różne formy praktyk pokutnych, które posiadają ważną wartość wychowawczo-leczniczą w życiu chrześcijanina. Drugi wskazuje na pokutę w aspekcie sakramentalnym, która nazywana jest spowiedzią. Jest ona aktem, w którym Kościół mocą Jezusa Chrystusa przez posługę kapłana odpuszcza pokutującemu grzechy. Pokuta sakramentalna posiada moc uzdrawiającą w wymiarze duchownym i wewnętrznym ${ }^{1}$.

Nadzwyczajny Jubileusz Miłosierdzia, który rozpoczął się w Kościele Katolickim dnia 8 grudnia 2015 roku w uroczystość Niepokalanego Poczęcia NMP i zakończył 20 listopada 2016 roku w uroczystość Jezusa Chrystusa Króla Wszechświata stał się również zachętą do pogłębienia refleksji na temat idei miłosierdzia w kontekście praktyki pokutej w tradycji Kościoła²

${ }^{*}$ Ks. dr hab. Michał Kieling, prof. UAM - profesor nadzwyczajny w Zakładzie Teologii Patrystycznej i Historii Kościoła na Wydziale Teologicznym Uniwersytetu im. Adama Mickiewicza w Poznaniu; e-mail: kieling@wp.pl.

${ }^{1}$ Por. W. Zawadzki, Pokuta, w: Leksykon Duchowości Katolickiej, red. M. Chmielewski, Lublin - Kraków 2002, 649-650.

${ }^{2} \mathrm{Na}$ temat pokuty i praktyk pokutnych w Kościele starożytnym: J. Bramborski, Rys historyczny sakramentu pokuty i pojednania, SG 15 (2001) 110-112; M. Chłopowiec, Pokuta w dokumentach synodalnych chrześcijańskiej starożytności, VoxP 30 (2010) t. 55, 121-134; S. Czerwik, Praktyka pokutna w Kościele poprzez wieki, AK 70 (1977) 159-177; B. Częsz, Duch Święty w Kościele a grzechy jego członków. Próby wyjaśnień u przednicejskich Ojców Kościoła, TPatr 1 (2004) 1928; M. Kieling, Grzechy i pokuta a świadomość świętości w późnej starożytności chrześcijańskiej, TPatr 1 (2004) 43-54; tenże, Dwanaście sposobów odpuszczenia grzechów? Praktyka pokutna wczesnośredniowiecznego Kościoła na podstawie Penitencjału Egberta, „Teologia Praktyczna” 13 (2012) 83-95; B. Kosecki, Wyznanie grzechów w praktyce pokuty Kościoła na Zachodzie, RBL (1976) 65-81; B. Mokrzycki, Kościót w oczyszczeniu, Warszawa 1986, 42-45; W. Myszor, Grzech i pokuta w Kościele III wieku, TPatr 1 (2004) 7-18; H. Pietras, Poczqtki teologii Kościoła, Kraków 2000; K. Sordyl, Próba rekonstrukcji doktryny i struktury kościoła nowacjańskiego, VoxP 32 (2012) 
Celem niniejszego artykułu jest przedstawienie ogólnych zasad odnoszących się do pokuty i praktyk penitencjarnych na podstawie Libri poenitentiales ${ }^{3}$. Księgi pokutne odegrały ważną rolę w kształtowaniu się pojęcia i form pokuty w Kościele zachodnim i dotyczyły wielu wymiarów życia indywidulanego i wspólnotowego chrześcijanina. Ich geneza sięga przełomu V/VI w. i prowadzi do tradycji Kościoła iro-szkockiego oraz brytyjskiego. W tamtejszych środowiskach monastycznych podjęto się zebrania zbiorów przepisów, praw, wskazówek i nauczania odnoszącego się do poszczególnych grzechów. W księgach pokutnych spotyka się również wpływy galijskie i italskie, które zapewne przenikały do tradycji monastycznej wczesnośredniowiecznych mnichów ${ }^{4}$. Księgi zawierają szczegółowe taryfikacje za popełnione grzechy. Charakterystyczne dla ksiąg są długie listy i katalogi grzechów, które ze szczególną precyzją dotyczą grzechów ciężkich. Zbiór ksiąg zatytułowany Libri poenitentiales został podzielony na księgi irlandzkie i brytyjskie (21 pozycji), galijskie i italskie (13 pozycji), hiszpańskie (4 pozycje) i greckie (2 pozycje) $)^{5}$.

Powyższy artykuł składa się z trzech części. W pierwszej zostanie przedstawione rozumienie pokuty jako duchowego lekarstwa. W drugiej zostanie ukazane nauczenie na temat dwunastu sposobów odpuszczenia grzechów. Natomiast $\mathrm{w}$ ostatniej zostaną zaprezentowane wskazówki odnoszące się do duchownych nakładających pokuty i pokutników.

1. Pokuta jako lekarstwo. Jednym z najczęstszych występujących określeń, odnoszących się do pokuty w okresie antycznym jest słowo lekarstwo (remedium). We wstępie do najstarszej, pochodzącej z ok. 550 r. Księgi pokutnej Finniana znajduje się następująca zachęta skierowana do pokutników:

„Gdyby ktoś zgrzeszył w swym sercu myślą i natychmiast okazał skruchę, winien uderzyć się w piersi, prosić Boga o łaskę i zadośćuczynić, a będzie zdrów. Gdyby często miał złe myśli i rozważał, co robić: ulec, czy nie ulec, niech prosi Boga o łaskę poprzez modlitwę i post, dniem i nocą, aż znikną bezbożne myśli i będzie zdrów"

Pokuta posiada zatem charakter uzdrawiający, a jej celem jest przywrócenie grzesznika do pełnego zdrowia duchowego. Penitencjał Finniana jest nie tylko katalogiem grzechów i stosowanych pokut za nie, ale wskazuje również na znaczenie miłosierdzia Bożego, jak również sposoby walki z grzechami

\footnotetext{
t. 57, 535-550; P. Wygralak, Praktyki pokutne w nauczaniu św. Cezarego z Arles, PzST 8 (1998) 99107; W. Zawadzki, Nauka o pokucie i praktyka pokutna w Kościele rzymskim w okresie starożytności chrześcijańskiej, VoxP 10 (1990) t. 19, 807-815.

${ }^{3}$ Por. Libri poenitentiales, ed. A. Baron - H. Pietras, Księgi pokutne, ŹMT 58, Kraków 2011 $=$ SCL 5 .

${ }^{4}$ Por. Wprowadzenie, w: Libri poenitentiales, ŹMT 58, XVI i XIX.

${ }^{5}$ Por. Libri poenitentiales, ŹMT 58, 1055-1058.

${ }^{6}$ Poenitentiale Vinniani 1-2, thum. A. Baron - J. Łukaszewska-Haberko - H. Pietras: Księga pokutna Finniana, ŹMT 58, 14-14*.
} 
i wadami ${ }^{7}$. W jego zakończeniu autor pokornie podkreśla, że pokuta jest swego rodzaju remedium:

„Najdrożsi bracia, tych kilka rzeczy o lekarstwach pokuty, kierując się miłością do was, starałem się napisać zgodnie z nauką pisma i zdaniem niektórych mędrców, ponad moje możliwości i uprawnienia"».

Księga pokutna św. Kolumbana, która datowana na 2. poł. VI w. podkreśla także terapeutyczny aspekt pokuty:

„Prawdziwa pokuta to nie popełniać grzechów, a popełniwszy, opłakiwać je. Jednak słabość wielu, by nie powiedzieć wszystkich, przeszkadza temu, zatem należy znać miary pokuty które przekazali święci ojcowie, aby zgodnie

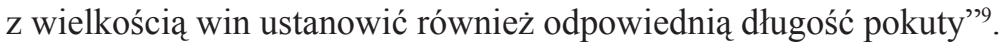

Kolumban rozróżnia pomiędzy grzechem, który ma miejsce w myślach i czynach. Jeśli ktoś chciałby w myślach zabić człowieka, dopuścić się nierządu, ukraść, zranić kogoś, skrycie sprzedać lub upić albo chciałby popełnić podobne grzechy, powinien za większe rzeczy pokutować przez pół roku, za mniejsze natomiast przez czterdzieści dni o chlebie i wodzie ${ }^{10}$. Sytuacja wyglądała inaczej w przypadku grzechów popełnionych czynem. Za morderstwo, grzech sodomii, pokutnik miał pokutować dziesięć lat. Za grzech nierządu w przypadku, kiedy został popełniony raz, pokuta trwała trzy lata; jeśli grzech ten popełniany był częściej, pokutę przedłużano do siedmiu lat. W księdze tej wymienione zostały konkretne choroby ciała i duszy, które wymagają interwencji:

„W związku z różnorodnością win, różne są również kary. Tak samo przecież i leczący ciała przepisują lekarstwa według różnych zasad. Inaczej leczą rany, inaczej choroby, jeszcze inaczej wzdęcia, siność, inaczej gangrenę, anemię, złamania i oparzenia. Podobnie lekarze ducha duchowe schorzenia, choroby, winy, bóle, niedomagania i słabości powinni leczyć różnymi metodami. Jednak lekarzy duchowych jest bardzo niewielu, zatem aby poznać te rzeczy, uleczyć i wzmocnić to, co słabe, wskazujemy nawet na nieliczne nakazy zgodnie z tradycją ojców i naszą"

„Duchowi lekarze” dokonują terapii na podobieństwo lekarzy ciała, którzy podejmują stosowne środki w odniesieniu do schorzeń cielesnych. W tym kontekście ważna jest informacja o tym, że niewielu jest lekarzy duszy. Wydaje się ona sugerować, że coraz więcej pokutników wyznawało swoje grzechy przed duchownymi, których liczba była niewystarczająca. Należy podkreślić,

\footnotetext{
${ }^{7}$ Por. B. Nadolski, Liturgika, t. 3: Sakramenty, sakramentalia, błogosławieństwa, Poznań 1992, 96.

${ }^{8}$ Poenitentiale Vinniani, ŹMT 58, 23-23*.

${ }^{9}$ Poenitentiale Sancti Columbani A 1, thum. S. Kalinkowski: Księga pokutna św. Kolumbana, ŹMT 58, 30-31*.

${ }^{10}$ Por. tamże.

${ }^{11}$ Tamże B Prologus, ŹMT 58, 32-33*.
} 
że ciężar pokuty był dostosowany do wielkości grzechu i stanu. Dlatego cięższa pokuta przysługiwała mnichom, a lżejsza ludziom świeckim. W zbiorze zatytułowanym $O$ różnych przewinieniach czyli Reguła klasztorna Kolumbana sformułowana jest zachęta skierowana dla mnichów, aby wyznawać grzechy lekkie i ciężkie:

„Najdrożsi bracia, świątobliwi ojcowie ustanowili przepis, abyśmy przed posiłkiem, przed udaniem się na spoczynek oraz w każdej stosownej chwili wyznawali wszystkie, nie tylko ciężkie grzechy, ale także mniejsze zaniedbania, albowiem wyznanie grzechów i pokuta wyzwalają od śmierci”"12.

Księga pokutna Pseudo-Kummeana, która pochodzi z VIII w. określa pokutę jako lekarstwo dla duszy. We wstępie do niej czytamy:

„Zaczyna się prolog o zbawiennych lekarstwach duszy. Mam zamiar powiedzieć ci o lekarstwach na rany zgodnie z tym, co powiedzieli ojcowie, nasi poprzednicy" ${ }^{\prime \prime}$.

W podobnym duchu znajdujemy zachętę do podejmowania pokuty we wstępie do księgi zatytułowanej Discipulus umbriensum, pochodzącej z przełomu VII/VIII w. Podkreślona jest w niej myśl, że różne sposoby pokutne to środki lecznicze, które pochodzą od Boga i zostały przekazane przez Ojców Kościoła. Sam bowiem Chrystus zachęcał do czynienia pokuty, którą na początku swojej misji głosił wszystkim jako lekarstwo dla źle się mających, mówiąc: „Czyńcie pokutę” $(\mathrm{Mt} \mathrm{4,17})^{14}$. Inne pismo ze zbiorów ksiag pokutnych zatytułowane Wyciag z kanonów Ojców Katolickich lub pokutne środki lecznicze dla dusz, arcybiskupa Egberta z Yorku, nazywane Wyciag Egberta ${ }^{15}$, jest ważnym świadectwem kształtowania się praktyki pokutnej w epoce wczesnego średniowiecza. Egbert z Yorku († 19 IX 766), był wczesnośredniowiecznym pedagogiem i kanonistą. Należał do grona wybitnych przedstawicieli odnowy intelektualno-duchowej, która miała miejsce na przełomie VIII/IX w. Był członkiem rodziny królewskiej, spokrewnionym z Ceolwulfem, królem Nortumbrii. Studiował w Rzymie, gdzie wstapił do zakonu benedyktynów. Po powrocie z Italii stał się słynny jako nauczyciel szkoły klasztornej w Yorku, której uczniem był znakomity uczony Alkuin. W 732 r. Egbert został biskupem, a w dwa lata później arcybiskupem Yorku ${ }^{16}$.

${ }^{12}$ Columbanus, De diversitate culparum sive Regula coenobialis, thum. S. Kalinkowski: Kolumban, O różnych przewinieniach czyli Reguła Klasztorna 1, ŹMT 58, 38-38*.

${ }^{13}$ Poenitentiale Cummaeani 1, thum. A. Baron - J. Lukaszewska-Haberko - H. Pietras: Ksiega pokutna Kummeana, ŹMT 58, 70-70*.

${ }^{14}$ Por. Discipulus Umbriensum, tłum. A. Baron, ŹMT 58, 131-132*.

${ }^{15}$ Excarpsum de canonibus catholicorum Patrum vel Poenitential ad remedium animarum domini Egberti archiepiscopi Eburacae civitatis, thum. A. Baron - A. Caba: Wyciag z kanonów Ojców Katolickich lub pokutne środki lecznicze dla dusz, arcybiskupa Egberta z Yorku, ŹMT 58, 181-193*.

${ }^{16}$ Por. M. Kieling, Terrena non amare sed coelestia. Theologie der Welt in Alkuins Commentaria super Ecclesiasten, Frankfurt am Main 2002, 9. 
Wyciag Egberta ukazuje pokutę jako lekarstwo dla wszystkich bolejących i pokutujących nad swoimi grzesznymi skłonnościami. Medycy, którzy przepisują lekarstwa jak również wywary na choroby, kierują się dobrem pacjenta i posługują się adekwatnymi środkami leczenia. Jeszcze bardziej odpowiedzialne zadanie nają kapłani, którzy stosują lekarstwa dla niewidzialnych dusz. Dlatego należy uważać, aby przez „głupiego medyka” rany nie stały się jeszcze gorsze ${ }^{17}$.

Ksiega pokutna Ps. Grzegorza III, napisana w IX w. zawiera excerpta z różnych ksiąg pokutnych. Jej autor wskazuje, że nazwa księgi pokutnej pochodzi od słowa ,pokutować”. Pokutuje zaś ten, kto żałuje i wstydzi się przed Bogiem swoich grzechów. Pokuta stanowi więc lekarstwo. Autor penitencjału stawia pytanie: jeśli lekarze ciała ustanawiają różne lekarstwa dla słabości cielesnych, o ile bardziej kapłani Boży winni zadawać zadośćuczynienia przeciw niegodnym i niezliczonym owocom uczynków cielesnych? ${ }^{18}$ Księga zawiera rozróżnienie osób, win, okoliczności i czasu. Ponadto podkreślono w niej, że w rozsądzaniu pokuty należy kierować się przede wszystkim mądrością. Ważne jest również podkreślenie miłosierdzia Bożego, które powinien otrzymać pokutujący, o czym przypomina Pismo Święte w słowach: „Synu, w sądzie bądź miłosierny" (Syr 4, 10). W tym kontekście przypomniana została myśl, że sąd bez miłosierdzia będzie dla tego, kto nie czynił miłosierdzia (por. Jk 2, 13).

Księgi pokutne opisują również czas trwania pokuty odnośnie do każdego grzechu, pozostawiając to raczej osądowi biskupów i prezbiterów, gdyż przed Bogiem nie jest ważny czas trwania pokuty, ale ból wewnętrzny; nie tyle wstrzemięźliwość od pokarmów, co raczej umartwienie ze względu na winy, dlatego czas pokuty był skracany przez wiarę i nawrócenie pokutujących ${ }^{19}$. Można powiedzieć, że księgi pokutne są swego rodzaju zbiorami receptur leczniczych na grzechy:

„Konieczne jest, aby ten leczniczy wyciag kapłani często czytali wiernym, wymawiali go z mądrością, starannie z pokorą, tam właśnie odnajdują uzdrowienie serca oraz lekarstwo dla duszy. W tej księdze znajduje się wielkie pocieszenie dla żałujących, błogosławiona nadzieja dla sprawiedliwych, uzdrowienie dla chorych, umocnienie i schronienie dla oskarżonych"20.

Penitencjał zwany Bigotianum, pochodzący z przełomu VIII/IX w. zawiera ogólne uwagi dotyczące pokuty, rozumianej jako lekarstwo na grzechy:

„O tyle większa skuteczność lekarza o ile bardziej wzmogła się choroba pacjenta. Stąd zajmujący się leczeniem ran innych, uważnie winni uwzględniać, w jakim celu i jakiej płci jest grzesznik, jakie otrzymał wykształcenie, jak jest

${ }^{17}$ Por. Excarpsum de canonibus catholicorum Patrum, ŹMT 58, 181-181*.

${ }^{18}$ Por. Poenitentiale Ps.-Gregorii III, Praefatio 1, thum. A. Baron - J. Lukaszewska-Haberko

- H. Pietras: Księa pokutna Ps.-Grzegorza III, ŹMT 58, 346-346*.

${ }^{19}$ Por. tamże, Praefatio 5, ŹMT 58, 347-347*.

${ }^{20}$ Tamże. 
dzielny, jaki kłopot przywiódł go do grzechu, jakie cierpienie go dręczy, jak długi czas trwał w przyjemnościach, jaki smutek i trud go trapią i jak odsuwa się od spraw świata" ${ }^{21}$.

Księga pokutna z Burgundii (ok. 700-725), najstarsza księga penitencjarna z Galii posługuje się obrazem grzechu, który porównany jest do choroby:

„Zróżnicowanie win pociaga za sobą różnorodność pokuty. Tak samo lekarze ciała przepisują lekarstwa według różnych zasad. Inaczej leczą rany, inaczej choroby, jeszcze inaczej wzdęcia, siność, inaczej gangrenę, anemię, złamania i oparzenia Podobnie duchowe schorzenia, choroby winy, bóle, niedomagania i słabości należy leczyć różnymi metodami”22.

W tym kontekście należy zwrócić uwagę jeszcze na jeden zbiór zatytułowany: Dekrety Burcharda, biskupa kościoła w Wormacji (ok. 1008-1012). Księga ta nazywana jest także Korektorem lub lekarzem, bo zawiera w pełni sposób poprawy ciała i lekarstwa dla duszy, a także poucza każdego kapłana, nawet prostego, w jaki sposób przychodzić z pomocą każdemu, zakonnikowi i świeckiemu, biednemu, bogatemu, dziecku, młodzieńcowi, starcowi, umierającemu, zdrowemu, choremu, w każdym wieku i obojga płci ${ }^{23}$. Znajduje się w niej zalecenie, aby na początku wielkiego postu zgromadzić wiernych, dając im możliwość pojednania i pokuty:

„(Z Penitencjału rzymskiego) $\mathrm{W}$ ostatnim tygodniu przed czterdziestnica, prezbiterzy winni zwołać do siebie lud, grzeszników pojednać na mocy kanonicznej władzy, wszystkie spory załagodzić, wyznaczyć pokutę wszystkim wyznającym grzechy w ten sposób, aby przed początkiem postu wszyscy spowiadający się przyjęli pokutę, aby łatwiej mogli powiedzieć: Odpuść nam nasze winy, jako i my odpuszczamy naszym winowajcom"24.

2. Dwanaście sposobów odpuszczenia grzechów. W kilku księgach pokutnych można znaleźć nauczanie o dwunastu sposobach odpuszczenia grzechów, które nazywa się zbawiennymi lekarstwami dla duszy. Po raz jest mowa o nich w Księdze pokutnej Kummeana:

„Pierwsze odpuszczenie dokonuje się w czasie naszego chrztu w wodzie, zgodnie z tym: «Dopóki ktoś nie odrodzi się z wody i z Ducha Świętego, nie może oglądać królestwa Bożego» (J 3, 5). Drugie to uczucie miłości, jak

${ }^{21}$ Paenitentiale quod dicitur Bigotianum 1-2, thum. A. Caba: Penitencjat zwany Bigotianum, ŹMT 58, 249-249*.

${ }^{22}$ Paenitentiale Burgundense, Prologus, thum. A. Baron - J. Łukaszewska-Haberko - H. Pietras: Ksiega pokutna z Burgundii, ŹMT 58, 261-261*.

${ }^{23}$ Burchardi Wormaciensis ecclesiae episcopi decretorum liber decimus nonus de poenitentia, Argumentum libri, tłum. B. Frontczak: Dekrety Burcharda, biskupa Kościoła w Wormacji, Księga dziewiętnasta o pokucie, ŹMT 58, 367-367*.

${ }^{24}$ Tamże 1, ŹMT 58, 367-367*. 
podają słowa: «Odpuszcza jej się wiele grzechów, ponieważ wielce umiłowała» (Łk 7, 47). Trzecie to owoc jałmużny, zgodnie z tym: «Jak woda gasi ogień, podobnie jałmużna zabija grzech» (Syr 3, 33). Czwarte to przelane łzy, bo Pan powiedział: «Ponieważ [Ahab] zapłakał w Mojej obecności i smutny chodzi przede Mną nie sprowadzę zła na jego dni» $(1 \mathrm{Krl} 21,29)$. Piąte to wyznanie win, jak mówi Psalmista: «Rzekłem, wyznam Bogu przeciwko sobie moją nieprawość, a ty przebaczyłeś mi bezbożność mego grzechu» (Ps 31, 5). Szóste to umartwienie serca i ciała, jak pociesza Apostoł: «Oddałem tego człowieka szatanowi, by zniszczył ciało a duch ocalał w dniu Pana naszego Jezusa Chrystusa» (1Kor 5, 5). Siódme to zmiana obyczajów, to znaczy odrzucenie wad, ponieważ poucza Ewangelista: «Jesteś już zdrowy, nie grzesz więcej, aby nie przydarzyło ci się coś gorszego» (J 5, 14). Ósme to wspomożenie świętych, jak powiedziano: «Jeśli ktoś osłabnie niech wezwie prezbiterów Kościoła, niech modlą się za niego, włożą na niego ręce, namaszczając go olejem w imię Pana, a modlitwa wiary ocali chorego i Pan go podźwignie, a jeśli był w grzechach, zostaną mu odpuszczone» (Jk 5, 14-15). Dziesiąte, nawrócenie i ocalenie innych, o czym zaświadczył Jakub: «Kto nawróciłby grzesznika z błędu jego życia, ocali jego duszę od śmierci i zgładzi wiele swych grzechów» (Jk 5, 16). Jednak lepiej dla ciebie, byś był zdrowy i prowadził życie samotne, niż je utracił z wieloma. Dziesiąte to miłosierdzie i zasługa wiary, zgodnie ze zdaniem: «Błogosławieni miłosierni, ponieważ oni miłosierdzia dostąpią» (Mt 5, 7). Jedenaste to nasze przebaczenie i odpuszczenie, obiecuje to Prawda, gdy mówi: «Odpuśćcie a będzie wam odpuszczone» (Łk 6, 37). Dwunaste to męczeństwo, jedyna nadzieja na przebaczenie i zbawienie jak Bóg powiedział łotrowi na krzyżu: «Zaprawdę powiadam ci, dziś będziesz ze mną w raju» (Łk 23, 43)"25.

Przedstawiając duchowe lekarstwa dla duszy, prowadzące do odpuszczenia grzechów, Kummean powołuje się na autorytet starożytnych kanonów. Nawiązuje przy tym do ośmiu grzechów głównych (principalia vitia), które leczyć należy przeciwnościami, zgodnie z przysłowiem: „Przeciwne leczy się przeciwnym"26. W powyższym zestawieniu dostrzegalny jest wpływ Orygenesa, który w Homiliach do Księgi Kapłańskiej pisze o możliwości pokuty za grzechy, które niekoniecznie były ciężkie, a dręczyły sumienia chrześcijan ${ }^{27}$. Aleksandryjczyk wymienia siedem sposobów odpuszczenia grzechów:

„Pierwszy sposób polega na tym, że przyjmujemy chrzest «na odpuszczenie grzechów» (Mk 1,3). Drugi sposób odpuszczenia grzechów zawiera się w męce męczeństwa. Trzeci rodzaj [odpuszczenia grzechów] osiągnąć można przez udzielanie jałmużny: powiada bowiem Zbawiciel: «raczej dajcie, co

${ }^{25}$ Poenitentiale Cummaeani 1-13, ŹMT 58, 70-71*.

${ }^{26}$ Tamże 15, ŹMT 58, 71-71*.

${ }^{27}$ Por. J. Słomka, Oczyszczenie z grzechu w homiliach Orygenesa o Księdze Kapłańskiej, SSHT 38 (2005) fasc. 2, 337-353. 
macie, a oto wszystko będzie w was czyste» (Łk 11, 41). Czwarty rodzaj odpuszczenia grzechów dokonuje się przez to, że i my odpuszczamy grzechy naszym braciom; oto tak mówi sam Pan i Zbawca: «Jeżeli z serca odpuścicie braciom waszym ich grzechy, to i wam odpuści grzechy wasz Ojciec. Jeśli zaś nie odpuścicie z serca braciom waszym, to i wam nie odpuści wasz Ojciec» (Mt 6, 14-15). [...] Piąty rodzaj odpuszczenia mamy wówczas, gdy «ktoś nawróci grzesznika z jego błędnej drogi»; tak bowiem mówi Pismo Boże: «Kto nawróci grzesznika z jego błędnej drogi, ocala duszę od śmierci i okrywa liczne grzechy» (Jk 5, 20). Szósty rodzaj odpuszczenia, dokonuje się przez pełnię miłości, a to zgodnie ze słowami Pana: «Zaprawdę, powiadam wam, odpuszczają się jej liczne grzechy, ponieważ bardzo umiłowała» (Łk 7, 47) [...]. Istnieje jeszcze siódmy sposób na uzyskanie odpuszczenia grzechów, a jest on twardy $i$ trudny - mianowicie przez pokutę, kiedy to grzesznik «łzami obmywa swoje łoże, a łzy są dla niego chlebem we dnie i w nocy» (Ps 6, 7; 41, 4), gdy nie wstydzi się wyznać grzechu swego kapłanowi Pańskiemu i szukać lekarstwa, tak jak ten, który rzekł: «Powiedziałem: 'Wyznam nieprawość moją wobec Pana', a Ty odpuściłeś grzech mojego serca» (Ps 31, 5)"228.

Kolejną księgą pokutna, w której znajdujemy nauczanie na temat dwunastu sposobów odpuszczenia grzechów jest Penitencjat Egberta ${ }^{29}$. W I księdze autor podaje najpierw krótsze zestawienie:

„Pierwszym odpuszczeniem jest chrzest, drugim - miłość Boga, trzecim gorliwość w udzielaniu jałmużny, czwartym - wylanie łez w prawdziwej skrusze, piątym - wyznanie złych czynów, szóstym - uniżenie serca i ciała w postach, siódme polega na poprawie obyczajów przed Bogiem, ósme to święte modlitwy za przewinienia, dziewiąte to miłosierdzie i dobra wiara, dziesiąte polega na tym, że innych od zła prowadzi się do Boga, jedenaste to odpuszczenie Boga, że Bóg przebacza grzechy, dwunaste to męczeństwo, jak było w przypadku łotra przy męce Chrystusa" 30 .

W IV księdze Penitencjału znajduje się także dłuższe zestawienie dwunastu sposobów odpuszczenia grzechów, ale tym razem autor uzupełnia je krótkimi wyjaśnieniami:

„Pierwsze odpuszczenie grzechów dokonuje się w obmyciu chrztu. Drugie odpuszczenie polega na miłości do Boga i do ludzi, kiedy ktoś całym sercem miłuje Boga, jak siebie kocha również swego bliźniego, to znaczy każdego chrześcijanina. Trzecie odpuszczenie dokonuje się poprzez rozdawanie

${ }^{28}$ Origenes, Homiliae in Leviticum 2, 4, ed. M. Borret, SCh 286, Paris 1985, 108-110, thum. S. Kalinkowski: Orygenes, Homilie o Księdze Kaptańskiej, PSP 31/2, Warszawa 1984, 17-18.

${ }^{29}$ Por. Kieling, Dwanaście sposobów odpuszczenia grzechów?, s. 83-95.

${ }^{30}$ Sancti Egberti Eboracensis archiepiscopi poenitentiale lib. I/1, 2, 10, thum. A. Baron - J. Łukaszewska-Haberko - H. Pietras: Penitencjat św. Egberta arcybiskupa Yorku w pięciu księgach, ŹMT 58, 204-204*. 
jałmużny, zostało bowiem napisane, że jak ogień gasi się wodą, tak jałmużna obmywa ludzkie grzechy. Czwarte odpuszczenie odbywa się przez psalmy i przelanie łez, gdy ktoś czyni pokutę za swoje grzechy i płacze tak, jakby zmarł jego przyjaciel. Piąte odpuszczenie dokonuje się przez wyznanie grzechów, gdy ktoś wyzna swoje grzechy spowiednikowi i wyjawi mu swe tajemnice, następnie wynagrodzi, jak ten mu nakaże. Szóste odpuszczenie dokonuje się, jeśli ktoś z miłości do Boga i dla zbawienia swej duszy przezwycięży nieprawe żądze swego ciała oraz tak dalece się doskonali przez post i inne cnoty, że jego człowieka wewnętrznego (por. Rz 7, 22; Ef 3, 16), czyli duszę, można uznać za pobożną. Siódme odpuszczenie dokonuje się, gdy ktoś swoje dobra, dzieci i ojczyznę opuści z miłości do Boga, uda się do obcej ziemi i tam zakończy swe życie. Ósme odpuszczenie dokonuje się, gdy ktoś odszedł skazany na śmierć, a jego przyjaciele, gdy jeszcze żył, mogli go wykupić i otrzymać dla niego odpuszczenie u Boga przez pobożną służbę i swe ziemskie posiadłości. Dziewiąte odpuszczenie to miłosierdzie i dobra wiara. Dziesiąte odpuszczenie, jeśli kogoś od grzechów nawrócimy do Bożej woli. Jedenaste odpuszczenie dokonuje się, gdy ktoś przez miłość do Boga odpuści winy tym, którzy wobec niego zawinili, bo Zbawiciel w swojej Ewangelii mówi: «Odpuśćcie, a będzie wam odpuszczone» (Łk 3, 37). Dwunaste odpuszczenie to męczeństwo, jakie przed Męką Pańską stało się udziałem łotra, gdy Zbawiciel mu powiedział: «Prawdziwie powiadam ci, jeszcze dzisiaj będziesz ze Mną w królestwie Ojca moego» (Łk 23, 43)"’31.

3. Wskazówki dla duchownych i penitentów. Libri poenitentiales zawierają także zalecania skierowane dla duchownych, którzy nakładali pokutę oraz penitentów. Księgi pokutne podkreślają, że lekarstwa na grzechy mające różne formy nie powinny być rozumiane jako autorytarne wskazówki, lecz pełne współczucia rady. Kanony pouczają, że nakładający pokutę powinien wziąć pod uwagę płeć, stan fizyczny, status i osobowość każdego pokutnika. Roztropność kapłańska polega także na umiejętnym stosowaniu praktyk pokutnych:

„Niech bacznie rozpozna serce pokutującego i stosownie do tego rozpoznania osądzi poszczególne rzeczy. Jednym poleci powstrzymywać się od pokarmów, innym udzielać jałmużny, niektórym częściej klękać lub stać w formie krzyża na modlitwie lub śpiewać psalmy, albo coś innego, co odnosi się do oczyszczenia z grzechów, a najliczniejszym - pełnienie ich wszystkich" ${ }^{32}$.

Księga Kummeana podkreśla, że przy każdym pokutniku należy wziąć pod uwagę następujące fakty: jak długo pozostawał w grzechu, jakie posiada wykształcenie, jaka była motywacja jego grzechu, czy okazywał żal oraz jak jest mocny:

${ }^{31}$ Tamże IV 60, ŹMT 58, 238-238*.

${ }^{32}$ Canones de remediis peccatorum I, tłum. A. Baron: Kanony o lekarstwach na grzechy, ŹMT 58, 194-194*. 
„Wszechmogący Bóg, który zna serca wszystkich i wprowadził różnorodność natur, nie zamierzył jednakowego ciężaru pokuty dla grzeszników, jak mówi proroctwo: «Nie młóci się czarnuszki saniami, ani koła wozu młocarskiego nie przetacza się po kminku, ani kijem wbija się czarnuszkę, a kminek cepami, ziarno bowiem by się zmiażdżyło» (Iz 28, 27-28)"33.

Kummean zauważa, że odpuszczenie grzechów jest prowadzeniem do pokuty, upominaniem, napominaniem, uczeniem, poprawieniem błędów, wyprowadzaniem z błędów oraz prowadzaniem do nawrócenia. Arcybiskup Yorku Egbert przestrzega natomiast przed wyborem kapłaństwa tych, którzy czynią to nie z powodu Boga, lecz dla zaszczytów ziemskich. Według niego w formacji duchowo-intelektualnej nie powinno zabraknąć miejsca na studium penitencjału:

„Kto zatem, bracia, pragnie przyjąć godność kapłańską, winien przede wszystkim myśleć o Bogu, winien przygotowywać jego oręż jeszcze zanim biskup nałoży na jego głowę ręce, to znaczy psałterz, lekcjonarz, antyfonarz, mszał, ryty chrztu, martyrologium, głoszenie kazań z dobrymi uczynkami w ciaggu roku, kalendarz i cykl [liturgiczny]. To jest prawo kapłańskie. Następnie niech starannie studiuje penitencjarz uporządkowany wedle autorytetu kanonów, dla rozpatrywania wszelkich spraw, bez których nie można wydać prawego sądu"34.

Autor penitencjału zachęca, aby każdego osądzać według właściwej miary: bogatego i biednego, wolnego i niewolnika, dziecko, chłopca, młodzieńca, dorosłego, człowieka w podeszłym wieku, duchownego, świeckiego, mnicha czy pełniącego posługi duchownego. Zachowanie kanonów prowadzi do zbawienia, a nie małoduszności. Autor przytacza w tym miejscu słowa Księgi Syracha: „W sądzeniu bądź miłosierny, łagodny jak ojciec i jakby mężem ich matki” (Syr 4, 10) oraz słowa Jakuba Apostoła: „Sąd bez miłosierdzia należy się temu, kto nie postępuje miłosiernie: miłosierdzie zaś winno przewyższać osąd" (Jk 2, 13).

Egbert z Yorku zwraca uwagę na przymioty, które winny charakteryzować osobę spowiednika. Przede wszystkim chodzi o postawę roztropności, która polega na odpowiednim rozeznaniu sytuacji penitenta ${ }^{35}$. Spowiednik powinien kierować się także zasadą sprawiedliwości:

„Wolno kapłanowi rozpatrywać zadośćuczynienie za grzechy wedle prawa biskupiego, i nie zważać na zamożnych ani na ubogich, jeśli im coś przykazuje, jak nakazuje księga. Mówi Zbawiciel, jeśli kapłan nie chce grzesznikowi wyznaczyć zadośćuczynienia za jego grzechu, że od niego zażąda jego duszy"’36.

\footnotetext{
${ }^{33}$ Poenitentiale Cummaeani, Epilogus 1, ŹMT 58, 85-85*.

${ }^{34}$ Excarpsum de canonibus catholicorum Patrum, ŹMT 58, 182-182*.

${ }^{35}$ Por. Sancti Egberti Eboracensis archiepiscopi poenitentiale lib. I/1, 1, ŹMT 58, 202-202*.

${ }^{36}$ Tamże I/2, 1, ŹMT 58, 217-217*.
} 
Właściwe rozeznanie jest wielką umiejętnością jaką powinien cechować się spowiednik:

„Ludzie mądrzy winni mieć na uwadze w ustaleniu miary pokuty, by zbrodni zasługującej na miecz nie karali kijem, a grzechu zasługującego na kij nie przebijali mieczem"37.

Księga pokutna Halitgariusa bpa Cambrai (817-830) wskazuje, że w ramach pokuty szczególne znaczenie posiadały posty. Kapłani powinni towarzyszyć w tych postach pokutującym przez dzień lub dwa, aby własnym przykładem zachęcić ich do przemiany życia:

„Nikt nie może podnieść upadłego pod ciężarem, jeśli się nie pochyli i nie wyciagnie do niego ręki. Podobnie żaden lekarz nie jest w stanie uleczyć chorego z ran, jeśli się nie narazi na fetor. Tak żaden z kałanów, ani biskup, nie może leczyć ran, ani odpuścić grzechów duszom, jeśli nie okaże pocieszenia i modlitwy ze łzami’"38.

Pochodzący z okresu karolińskiego penitencjał podkreśla troskę penitenta o grzesznika:

„Przeto i my, jeśli zobaczymy kogoś leżącego w grzechach, spieszymy, aby go przywołać do pokuty wedle naszej nauki. Ilekroć dajesz pouczenie grzesznikowi; natychmiast daj mu pokutę: ile powinien pościć i odkupić swe grzechy"39.

Powyższa księga pokutna podkreśla, że tak jak ofiarę sprawują prezbiterzy i biskupi, którym przekazano klucze królestwa niebieskiego, inni nie mogą sobie uzurpować władzy osądu. W razie konieczności dopuszczano, aby w sytuacji, kiedy nie było prezbitera, diakon mógł przyjąć prezbitera do zadośćuczynienia i świętej komunii. Biskupi oraz kapłani winni być blisko pokutujących, modląc się za nich i wylewając łzy:

„Kiedy więc ktoś przybywa do kapłana, aby wyznać swoje grzechy, niech mu kapłan przekaże, aby chwilę poczekał, a sam pójdzie do pokoju na modlitwę. Gdyby zaś nie miał osobnego pomieszczenia, niech wypowie modlitwę w sercu”"40.

Księga pokutna zawiera również modlitwę, jaką kapłan odmawiał nad przychodzącym do pokuty:

„Panie Boże wszechmogący, bądź litościw mnie grzesznemu, abym mógł godnie Ci podziękować, Tobie, który mnie niegodnego dzięki Twemu miłosierdziu uczyniłeś szafarzem kapłańskiego urzędu i mnie marnego i małego

${ }^{37}$ Paenitentiale quod dicitur Bigotianum 3, ŹMT 58, 249-249*.

${ }^{38}$ Poenitentiale Halitgarii ep. Camaracensis II 1, thum. A. Baron - J. Lukaszewska-Haberko H. Pietras: Księga pokutna Halitgariusa, bpa Cambrai, ŹMT 59, 314-314*.

${ }^{39}$ Tamże II 2, ŹMT 58, 315-315*.

${ }^{40}$ Tamże II 4, ŹMT 58, 315-315*. 
ustanowiłeś pośrednikiem dla modlitwy i wstawiania się u Pana naszego Jezusa Chrystusa za grzeszników i zwracających się do pokuty" ${ }^{\text {"41 }}$.

Wśród zaleceń skierowanych do spowiednika należy zwrócić uwagę na następującą wskazówkę:

„Jeśli ujrzysz, że ktokolwiek przystępuje z zapałem i wytrwałością, tego przyjmij. Kto może pościć tyle, ile mu nałożono, nie wzbraniaj mu tego, lecz pozwól. Należy bardziej chwalić tych, którzy spiesznie chcą uwolnić się od należnego ciężaru, bo post jest konieczny. W taki sposób dawajcie pouczenie tym, którzy sprawują pokutę: jeśli pościł i wypełnił to, co mu nakazał kapłan, zostanie oczyszczony z grzechów. Gdyby powtórnie wrócił do złego nawyku i grzechu, to jest jak pies, który powraca do swoich wymiocin (por. Prz 26, 11; 2P 2, 22)"'42.

Księga pokutna Halitgariusza zawiera porządek modlitw przy wyznaczeniu pokuty: na początku kapłan miał odmówić psalm 37., następnie psalm 102. oraz psalm 50. Po odmówieniu psalmów następowała modlitwa:

„Boże, którego łaskawości potrzebuje każdy człowiek, pamiętaj o słudze twoim N., który obnaża w słabości swe rozwiązłe i ziemskie ciało. Prosimy, okaż łaskę wyznającemu, oszczędź błagającego, abyśmy, których oskarżają własne winy, zostali zbawieni dzięki Twemu miłosierdziu. Przez Pana naszego Jezusa Chrystusa"43.

Następnie następowało nałożenie rąk z prośbą skierowaną do Boga, aby odpuścił wszystkie grzechy i przewinienia.

W podobnym duchu Dekrety Burcharda ukazują, w jaki sposób kapłani powinni napominać i pouczać w czasie pokuty powierzony im lud:

„(Z Augustyna). Prezbiterzy powinni napominać powierzony im lud, aby każdy, kto czuje się zraniony śmiertelną raną grzechu, w środę przed czterdziestnicą z pospiechem przybiegł do życiodajnej matki Kościoła, gdzie, czego złego się dopuścił, z cała pokorą i skruchą serca pokornie wyzna i przyjmie lekarstwo pokuty według sposobu zatwierdzonego autorytetem kanonów. [...] Biskupi lub prezbiterzy, kiedy przyjmą wyznanie wiernych, powinni się upokorzyć i modlić się ze smutkiem i łzami, nie tylko za swoje grzechy, ale także za grzechy brata. Mówi bowiem Apostoł: «Któż odczuwa słabość, czyż i ja nie jestem słaby?» (2Kor 11, 29). Zatem, gdy przyjdzie ktoś do kapłana, aby wyznać swoje grzechy, kapłan niech mu poleci, aby odczekał trochę nim wejdzie do kościoła, albo do swojego pokoju, by się modlić. Natomiast jeśli miejsce nie jest do tego odpowiednie, niech tę modlitwę odmówi w swoim sercu" ${ }^{44}$.

\footnotetext{
${ }^{41}$ Tamże.

${ }^{42}$ Tamże II 6, ŹMT 58, 316-316*.

${ }^{43}$ Tamże III 2, ŹMT 58, 317-317*.

${ }^{44}$ Burchardi Wormacensis ecclesiae episcopi decretorum liber decimus nonus de poenitentia II, ŹMT 58, 367-368*.
} 
Oprócz wskazówek skierowanych do duchownych w księgach pokutnych można znaleźć również nauczanie na temat przygotowania penitentów do pokuty. W praefatio do Penitencjatu Egberta znaleźć można następujące zalecenia:

„Jeśli kto przystępuje do pokuty (ad poenitentiam), niech się pochyli z największą bojaźnią Bożą i pokorą wobec Niego. Niech modli się błagalnym głosem, aby nauczył go pokutować za wszystkie wykroczenia, które uczynił wbrew Bożej woli. Niech wyzna wszystkie swe złe uczynki, aby kapłan poznał, jaką winien nałożyć mu pokutę. Następnie niech wypyta go kapłan, czy ma wiarę w Boga; niech go zachęca na różne sposoby ze względu na potrzeby jego duszy i napomina"45.

Powyższy tekst poświadcza praktykę indywidualnej pokuty, która polegała na wyznaniu grzechów przed kapłanem. Podczas tego spotkania kapłan stawiał pokutnikowi pytania dotyczące wiary w Boga w Trójcy Jedynego, wiary w zmartwychwstanie w dniu sądu, i pytał o żal za wszystkie grzechy dokonane myślą lub uczynkiem. Na zakończenie spowiednik stawiał pytanie o gotowość przebaczenia wszystkim, którzy kiedykolwiek zawinili przeciw pokutnikowi ${ }^{46}$. Jeżeli na postawione zapytania pokutnik odpowiedział „chcę”, to wówczas udzielano mu następującego pouczenia:

„Bóg miłosierny niech się nad tobą zlituje, a mnie zezwoli na to, co powinienem [uczynić]. Pość tyle a tyle dni w tym czasie czterdziestnicy aż do godziny dziewiątej, powstrzymuj się [od jedzenia] od świtu, strzeż się ośmiu grzechów głównych, to znaczy zabójstwa, kradzieży, krzywoprzysięstwa, chytrości, nieprawego spółkowania, zbytku, oszczerstwa i fałszywego świadectwa; przestrzegaj dwunastu dni postów czterdziestodniowych, które następują każdego roku; wystrzegaj się ofiar barbarzyńskich, magii, współżycia z dziewica, fałszywej mowy, pychy i chęci posiadania innych ludzi; wystrzegaj się tego wszystkiego; wiernie miłuj Pana swego z całej duszy, z cała odwagą, ze wszystkich sił i całym sercem" ${ }^{\prime 4}$.

W powyższych słowach znajduje się zachęta do podejmowania postów, do unikania ośmiu grzechów głównych, odrzucenia bałwochwalstwa, magii oraz zachęta do miłości Boga i bliźniego. Kapłan zwracał również uwagę na postawę miłosierdzia u grzesznika, która przejawia się w szczodrości wobec biednych, łagodności, udzielaniu jałmużny, nawiedzaniu kościołów, sumiennym dawaniu dziesięciny. W ten sposób grzesznik zasługiwał na nagrodę życia wiecznego w niebie ${ }^{48}$. W księdze znajduje się rada dla tych, którzy chcieliby czynić pokutę, ale powątpiewają:

\footnotetext{
${ }^{45}$ Sancti Egberti Eboracensis archiepiscopi poenitentiale lib., Praefatio, ŹMT 58, 201-201*.

${ }^{46}$ Por. tamże.

${ }^{47}$ Tamże, s. 201-202*.

${ }^{48}$ Por. tamże I/1, 1, ŹMT 58, 202-202*.
} 
„Wielu ludzi chciałoby podjać pokutę, jednak wahają się ze względu na wielość swych grzechów, powątpiewają, czy będą mogli unieść to, co im wyznaczy spowiednik, i rezygnują. Uważa się, że wtedy zwątpienie jest większym grzechem niż te, które zamierzał wyznać i czego zaniechał"49.

Pokutnik powinien powstrzymywać się w wielu sprawach od pragnień swego życia: po pierwsze powinien pokutować za wszystko, w czym uchybił Bogu, a następnie unikać wszystkiego, co drogie jest ciału ze względu na umiłowanie życia wiecznego ${ }^{50}$. Po wypełnieniu pokuty pokutnik nie powinien wracać do dawnych grzechów, odrzucając ducha tego świata:

„Pismo Święte mówi, że nie wypada, by pokutnik, gdy wypełnił to, co nakazał mu spowiednik, zajmował się rzeczami światowymi i nie pamiętał o pokucie, którą wcześniej wypełnił, ponieważ św. Paweł mówi: Ten, kto chce służyć Bogu nie może się zajmować sprawami tego świata (por. 1Kor 7, 32-34)"s1.

$* * *$

Księgi pokutne, które powstały w epoce późnej starożytności chrześcijańskiej i wczesnego średniowiecza są świadectwem kształtowania się praktyki pokutnej w Kościele. Ukazują one przywiązanie do tradycji Ojców oraz rozumienie pokuty jako duchowego lekarstwa na duchowe choroby. Należy wskazać na bogactwo praktyk oraz ich duchowe znaczenie w życiu chrześcijanina, które nie ograniczało się tylko do postu, jałmużny i modlitwy, ale dotyczyło wielu innych aspektów życia wewnętrznego i społecznego. W tym względzie nauczanie na temat dwunastu lekarstw na choroby duszy lub dwunastu sposobów odpuszczenia grzechów może być dla współczesnego człowieka zachętą do bardziej wewnętrznego i ewangelicznego rozumienia pokuty. Libri poenitentiales są także świadectwem przełomu w praktyce pokutnej Kościoła, polegającej na tym, że we wczesnym średniowieczu pojawia się forma indywidualnej i powtarzalnej spowiedzi. Dlatego w niektórych księgach znajdujemy opis rytu sakramentu spowiedzi. W tym kontekście na szczególną uwage zasługują wskazówki skierowane do duchownych, którzy nakładali pokutę i penitentów, którzy wyznawali swoje grzechy. Księgi pokutne podkreślają, że w procesie nawrócenia ważną rolę posiada łaska Bożego Miłosierdzia oraz postawa grzesznika, który przez wykonywanie praktyk pokutnych zmienia swoje nastawienie wewnętrzne i zewnętrzny sposób życia.

\footnotetext{
${ }^{49}$ Tamże I/2, 4, 1, ŹMT 58, 218-218*.

${ }^{50}$ Por. tamże I/2, 5, ŹMT 58, 218-218*.

${ }^{51}$ Tamże I/2, 7, ŹMT 58, 219-219*.
} 


\section{GENERAL PRINCIPLES CONCERNING PENITENTIAL PRACTICES ON THE BASIS OF LIBRI POENITENTIALES}

\section{(Summary)}

The article discusses the most important premises which deal with Christian penance from the VI to the XI century. The main sources for the above article are the Penitential Books (Libri Poenitentiales), published as part of the series of Źródła Myśli Teologicznej (ŻMT 58), collected and edited by A. Baron and H. Pietras in 2011. The article consists of three parts. The first part examines the meaning of penance in the life of Christians as a medicine for sin which is an illness of the soul and the body. The second part presents the teaching of penitentials on the twelve ways of absolving from sins. The third part provides practical suggestions for confessors and penitents. The Penitential Books, as a witness to the development of penitential practices, confirm the role of individual spiritual therapy in the life of the Christian. This process of regaining of one's spiritual health takes place, on one hand, through the grace of God's Mercy, and, on the other hand, through penitential practices whose aim was internal conversion and outward change in one's way of life.

Key words: Penitential books, penance, penitential practices in the Church, ways of granting absolution.

Słowa kluczowe: Księgi pokutne, pokuta, praktyka pokutna w Kościele, sposoby odpuszczenia grzechów.

\section{BIBLIOGRAFIA}

\section{Źródła}

Libri poenitentiales, ed. A. Baron - H. Pietras, Księgi pokutne, ŹMT 58, Kraków 2011 $=$ SCL 5.

Origenes, Homiliae in Leviticum, ed. M. Borret, SCh 286-287, Paris 1981, thum. S. Kalinkowski: Orygenes, Homilie o Księdze Kapłańskiej, PSP 31/2, Warszawa 1985.

\section{Opracowania}

BRAmborski J., Rys historyczny sakramentu pokuty i pojednania, SG 15 (2001) 110-112.

ChŁopowiec M., Pokuta w dokumentach synodalnych chrześcijańskiej starożytności, VoxP 30 (2010) t. 55, 121-134.

Czerwik S., Praktyka pokutna w Kościele poprzez wieki, AK 70 (1977) 159-177.

CzĘSz B., Duch Swięty w Kościele a grzechy jego członków. Próby wyjaśnień u przednicjeskich Ojców Kościoła, TPatr 1 (2004) 19-28.

KIELING M., Terrena non amare sed coelestia. Theologie der Welt in Alkuins Commentaria super Ecclesiasten, Frankfurt am Main 2002.

KIELING M., Grzechy $i$ pokuta a świadomość świętości $w$ późnej starożytności chrześcijańskiej, TPatr 1 (2004) 43-54. 
KIELING M., Dwanaście sposobów odpuszczenia grzechów? Praktyka pokutna wczesnośredniowiecznego Kościoła na podstawie Penitencjału Egberta, „Teologia Praktyczna" 13 (2012) 83-95.

KosECKI B., Wyznanie grzechów w praktyce pokuty Kościoła na Zachodzie, RBL (1976) 65-81.

Mokrzycki B., Kościół w oczyszczeniu, Warszawa 1986.

Myszor W., Grzech i pokuta w Kościele III wieku, TPatr 1 (2004) 7-18.

Nadolski B., Liturgika, t. 3: Sakramenty, sakramentalia, błogosławieństwa, Poznań 1992.

Pietras H., Poczatki teologii Kościoła, Kraków 2000.

SŁOмKa J., Oczyszczenie z grzechu w homiliach Orygenesa o Księdze Kapłańskiej, SSHT 38 (2005) fasc. 2, 337-353.

SoRdyl K., Próba rekonstrukcji doktryny i struktury kościoła nowacjańskiego VoxP 32 (2012) t. 57, 535-550.

Wygralak P., Praktyki pokutne w nauczaniu św. Cezarego z Arles, PzST 8 (1998) 99-107.

ZAWADZKI W, Nauka o pokucie i praktyka pokutna $w$ Kościele rzymskim $w$ okresie starożytności chrześcijańskiej, VoxP 10 (1990) t. 19, 807-815.

ZawadzKi W., Pokuta, w: Leksykon Duchowości Katolickiej, red. M. Chmielewski, Lublin - Kraków 2002, 649-650. 